J. Pijar MIPA, Vol. V No.2, September : 53 - 56

ISSN 1907-1744

\title{
DAMPAK PENERAPAN PENDEKATAN PEMBELAJARAN KOOPERATIF TIPE LEARNING TOGETHER (LT) YANG DIMODIFIKASI DENGAN BERGANTI PERAN DAN PERAN TETAP TERHADAP HASIL BELAJAR KIMIA ANORGANIK 1
}

\author{
Jeckson Siahaan \\ Program Studi Pendidikan Kimia PMIPA FKIP Universitas Matarm \\ Jl. Majapahit No. 62 Mataram 83125
}

\begin{abstract}
Abstrak : Tujuan dari penelitian ini adalah untuk mengetahui perbedaan hasil belajar mahasiswa antara yang diajar dengan pendekatan pembelajaran ceramah dan yang diajar dengan pendekatan pembelajaran kooperatif tipe $L T$ yang dimodifikasi dengan berganti peran dan peran tetap. Penelitian ini dilakukan di Universitas Mataram dengan menerapkan rancangan eksperimen semu. Subjek penelitian adalah mahasiswa Program Studi Kimia, FMIPA, sebagai kelas eksperimen dan mahasiswa Program Studi Pendidikan Kimia, FKIP, sebagai kelas kontrol tahun ajaran 2007/ 2008. Data penelitian terdiri dari hasil belajar mahasiswa berupa tes hasil belajar dengan validitas isi sebesar $97,8 \%$ dan koefisien reliabilitas diukur dengan metode paralel, sebesar 0,81. Hasil-hasil penelitian ini menunjukkan bahwa pendekatan pembelajaran kooperatif tipe $L T$ yang dimodifikasi dengan berganti peran dan peran tetap lebih baik dibanding pendekatan pembelajaran ceramah, dan berganti peran lebih baik dibanding peran tetap.

Kata kunci : Pembelajaran kooperatif, berganti peran, peran tetap, hasil belajar.

\section{THE EFFECT OF COOPERATIVE LEARNING OF LEARNING TOGETHER $(L T)$ TYPE, MODIFIED FOR EXCHANGE AND PERMANENT ROLES, UPON STUDENTS' ACHIEVEMENT IN INORGANIC CHEMISTRY 1.}

Abstract : The aims of this research are to find out the differences of the results of study of Inorganic Chemistry course between students who teached with convensional learning approach versus cooperative learning type of learning together approaches modified for exchange and permanent roles. This investigation applied a quasi-experimental design and has conducted at Mataram University. Subjects of this research were students of chemistry study program of faculty of mathematic and science as an experimental group and students of chemistry education study program of faculty of teacher training and education as a control group in the academic year of 2007/2008. The data of this research consist of students! result study generated from essay test with content validity was $97.8 \%$ and reliability coefficient measured by parallel method was .81 . The results showed that cooperative learning type of learning together approach modified for exchange and permanent roles were better than convensional learning ones, and exchange role was better than permanent one.
\end{abstract}

Keywords : Cooperative learning, learning together, exchange role, permanent role, achievement, perception.

\section{PENDAHULUAN}

Selama ini pembelajaran mata kuliah Kimia Anorganik 1 dilaksanakan dengan pendekatan pembelajaran ceramah baik kegiatan praktikum di laboratorium maupun pembelajaran kuliah teori di kelas. Pembelajaran seperti ini mengikuti paradigma pembelajaran behavioristik (teacher centered) dengan memberikan penekanan pada transfer pengetahuan dan latihan soal-soal. Pembelajaran seperti ini kurang memperhatikan aktifitas mahasiswa, interaksi mahasiswa, negosiasi makna, dan konstruksi pengetahuan[4]. Dampak dari pembelajaran ini adalah sebagian dari mahasiswa mengalami kesulitan menguasai materi kuliah sehingga tidak dapat memenuhi tuntutan kompetensi di atas.

Untuk membantu mahasiswa mengatasi kesulitan menguasai materi ajar, perlu dilakukan perubahan pembelajaran dari paradigma behavioristik (teacher centered) ke paradigma konstruktivistik (student centered). Paradigma ini menyiratkan bahwa pembaharuan pembelajaran kimia pada dasarnya dimulai dari bagaimana cara mahasiswa belajar dan bagaimana cara dosen mengajar yang pada gilirannya adalah bagaimana cara mahasiswa mengkonstruksi pengetahuannya. Berdasarkan pandangan itu, maka semua pembelajaran dapat dilakukan dengan menggunakan suatu pendekatan pembelajaran yang bersifat konstruktivistik [4] .
Menurut Vygotsky [7], cara untuk menciptakan pembelajaran konstruktivistik adalah dengan memberi penekanan pada pentingnya scaffolding atau mediated learning. Scaffolding adalah merupakan syarat-syarat atau langkah-langkah atau fase-fase yang diterapkan dalam pembelajaran konstruktivistik yang berguna untuk membantu mahasiswa memahami materi ajar. Upaya yang bisa dilakukan untuk memperoleh scaffolding atau mediated learning adalah dengan menerapkan pembelajaran konstruktivistik yang sesuai dengan karakteristik bidang studi, misalnya, pendekatan pembelajaran kooperatif.

Tujuan dari penelitian ini adalah untuk mengetahui perbedaan hasil belajar Kimia Anorganik 1 antara: 1) kelompok mahasiswa yang diajar dengan pendekatan pembelajaran kooperatif tipe $L T$ yang dimodifikasi dengan berganti peran dan peran tetap dan kelompok mahasiswa yang diajar dengan pendekatan pembelajaran ceramah, 2) mengetahui persepsi mahasiswa tentang pendekatan pembelajaran kooperatif tipe $L T$ yang dimodifikasi dengan berganti peran dan peran tetap.

\section{Pendekatan Pembelajaran Kooperatif}

Menurut Slavin, filosofi dan teori pembelajaran kooperatif dapat didefinisikan sebagai "cooperative learning method shares the idea that students work together to learn and are responsible for one another's 
learning as well as their own" [7]. Definisi ini mengandung pengertian bahwa dalam pembelajaran kooperatif siswa belajar bersama, saling menyumbangkan pikiran dan bertanggung jawab terhadap pencapaian hasil belajar secara individu maupun kelompok. Perasaan saling bertanggung jawab ini sering diistilahkan dengan "swim and sink together".

Menurut Cohen, pembelajaran kooperatif sebagai "cooperative learning will be defined as students working together in a group small enough that everyone can participate on a collective task that has been clearly assigned. Moreover, students are expected to carry out their task without direct and immediate supervision of the teacher" [7]. Definisi ini disamping memiliki pengertian luas yang meliputi belajar berkolaborasi, belajar kooperatif dan kerja kelompok, juga menunjukkan ciri sosiologis yaitu penekanannya pada aspek tugas-tugas kolektif yang harus dikerjakan bersama dalam kelompok dan pendelegasian wewenang (authority) dari guru kepada siswa. Guru berperan sebagai fasilitator dalam membimbing siswa menyelesaikan materi tugas.

Seperti pendekatan pembelajaran STL (Student Team Learning), pendekatan pembelajaran $L T$ (Learning Together) berakar dari teori motivasi. Pengembang $L T$, David Johnson dan Roger Johnson, mendasarkan hasil kerjanya pada apa yang digagas oleh Morton Deutcsh, yang dibangun dari teori motivasional Kurt Lewin [5].

Pendekatan Pembelajaran Kooperatif Tipe Learning Together (LT)

Pendekatan pembelajaran kooperatif tipe Learning Together ( $L T)$, dikembangkan oleh David dan Roger Johnson berdasarkan pada teori psikologi sosial Morton Deutsch dan dari teori motivasional Kurt Lewin [5]. Siswa bekerja dalam kelompok kecil untuk menghasilkan suatu proyek kelompok. Konsep kunci pembelajaran kooperatif model $L T$ adalah "interdependence" yang menekankan pada persepsi bagaimana orang saling mempengaruhi oleh apa yang terjadi pada yang lain [6].

$L T$ melibatkan lima prinsip dimana peneliti dapat mengaplikasikannya dalam berbagai cara, dalam situasi yang luas, dan dengan kurikulum dan materi yang ada. Kelima persyaratan Johnson untuk $L T$ [5] adalah: (1) saling ketergantungan positif (positive interdependence), (2) mengutamakan interaksi tatap muka (face-to-face promotive interaction), (3) tanggung jawab individual (individual accountability), (4) keterampilan interpersonal dan kelompok kecil (interpersonal and small group skills), dan (5) pemrosesan kelompok (group processing).

\section{METODE PENELITIAN}

Penelitian ini dilaksanakan dengan menggunakan rancangan eksperimen semu (quasi experiment). Untuk menentukan kelas-kelas eksperimen dan kelas kontrol dilakukan dengan teknik sampling kelompok atau cluster random sampling karena populasi berada dalam kelompok-kelompok atau cluster. Pengambilan sampel terdiri dari dua langkah. Pertama, pemilihan sampel secara acak dari kelompok-kelompok subjek penelitian melalui teknik undian. Kedua, mengambil semua subjek yang tercakup dalam kelompok yang terpilih sebagai anggota sampel [3].

Subjek penelitian adalah mahasiswa Program Studi Kimia, FMIPA, dan mahasiswa Program Studi Pendidikan Kimia, Jurusan Pendidikan MIPA, FKIP, Universitas Mataram tahun akademi 2007/2008. Subjek penelitian dibagi dalam tiga kelompok: satu kelompok kontrol dan dua kelompok eksperimen.

Penelitian ini melibatkan dua macam variabel, yaitu variabel bebas dan variabel terikat. Variabel bebas pada penelitian ini adalah pendekatan pembelajaran koperatif tipe $L T$ yang dimodifikasi dengan berganti peran dan peran tetap, sedangkan variable terikat adalah hasil belajar [8]. Disamping itu terdapat juga variabel kontrol, yaitu faktor-faktor yang dikontrol atau dinetralkan pengaruhnya oleh peneliti, karena jika tidak demikian diduga ikut mempengaruhi hubungan antara variabel bebas dengan variabel terikat, seperti: (1) kemampuan intelektual, sikap, dan kesungguhan peneliti dalam melaksanakan pembelajaran, (2) fasilitas pembelajaran, (3) jenis dan waktu tes, (4) kurikulum yang digunakan, materi pembelajaran, dan waktu pembelajaran. Variabelvariabel ini diasumsikan konstan sehingga tidak mempengaruhi variabel bebas. Variabel lainnya adalah variabel moderator, yaitu sebuah tipe khusus variabel bebas; variabel bebas sekunder yang diangkat untuk menentukan apakah ia mempengaruhi hubungan antara variabel bebas primer dan variabel terikat. Variabel moderator adalah faktor yang diukur, dimanipulasi atau dipilih peneliti untuk mengungkap apakah faktor tersebut mengubah hubungan antara variabel bebas dan variabel terikat. Pada penelitian ini yang menjadi variabel moderator adalah berganti peran dan peran tetap.

Instrumen penelitian yang digunakan dalam penelitian ini terdiri dari instrumen perlakuan berupa silabus (termasuk petunjuk praktikum) dan SAP (Satuan Acara Pembelajaran) dan instrumen pengukuran berupa soal-soal essay.

Prosedur pengumpulan data dalam penelitian ini adalah sebagai berikut[3]:

\begin{tabular}{|l|c|c|}
\hline $\begin{array}{c}\text { Tujuan } \\
\text { Pengumpulan } \\
\text { Data }\end{array}$ & $\begin{array}{c}\text { Data Yang } \\
\text { Diperlukan }\end{array}$ & $\begin{array}{c}\text { Prosedur } \\
\text { Pengumpulan } \\
\text { Data }\end{array}$ \\
\hline $\begin{array}{l}\text { Mengetahui } \\
\text { hasil belajar } \\
\text { mahasiswa }\end{array}$ & Skor postes & Tes essay \\
\hline
\end{tabular}

\section{Uji Persyaratan Instrumen Penelitian}

Uji persyaratan untuk instrumen penelitian yang berupa tes hasil belajar, lembar observasi untuk mengukur nilai afektif dan performansi (kinerja) meliputi uji validitas dan uji reliabilitas.

Validitas Instrumen Tes Hasil Belajar

Uji validitas instrumen tes hasil belajar yang dilakukan adalah validitas isi, yaitu instrumen yang dapat digunakan untuk mengukur kemampuan yang diinginkan dari mahasiswa [2]. Validitas isi ditetapkan berdasarkan penilaian dari ahli-ahli pendidikan kimia dibidangnya. 
Reliabilitas $\left(r_{11}\right)$ Tes Hasil Belajar

Rumus yang digunakan untuk menentukan reliabilitas tes adalah rumus Kuder - Richardson 20 (KR20):

$$
r_{11}=\left(\frac{n}{n-1}\right)\left(\frac{S^{2}-\sum p q}{S^{2}}\right)
$$

Keterangan:

$r_{11}=$ reliabilitas tes secara keseluruhan

$n=$ jumlah butir soal

$\mathrm{S}=$ standar devias

$\mathrm{p}=$ proporsi siswa yang menjawab benar

$\mathrm{q}=$ proporsi siswa yang menjawab salah

Reliabilitas Perangkat Tes

\begin{tabular}{|l|l|}
\hline Koefisien Korelasi & Kategori \\
\hline $0,81<r_{x y}=1,00$ & Tinggi \\
$0,61<r_{x y}=0,80$ & cukup \\
$0,41<r_{x y}=0,60$ & sedang \\
$0,21<r_{x y}=0,40$ & rendah \\
$0,00<r_{x y}=0,20$ & sangat rendah \\
\hline
\end{tabular}

Dari hasil perhitungan dengan menggunakan program EXCEL diperoleh reliabilitas tes sebesar 0,81, termasuk dalam kriteria reliabilitas dengan tingkat yang tinggi sehingga dapat dipercaya sebagai instrumen penelitian.

\section{Langkah-langkah Pelaksanaan Penelitian}

1). Persiapan

2). Proses Belajar/Pelaksanaan penelitian

Pelaksanaan penelitian ini mengacu pada sintaks pembelajaran kooperatif tipe $L T$ yang dimodifikasi dengan berganti peran dan peran tetap. Untuk melihat proses pembelajaran dilakukan dengan memberikan LKM (lembar kerja mahasiswa) berupa pertanyaan-pertanyaan yang menuntut kompetensi mahasiswa dalam hal pemahaman akan: (a) penggolongan unsur, (b) keperiodikan sifat unsur, dan (c) konsep-konsep dasar reaksi Kimia Anorganik. Pokok-pokok bahasan lainnya masing-masing terdiri atas beberapa sub-pokok bahasan seperti: (a) sumber-sumber unsur di alam, (b) cara-cara ekstraksi unsur, (c) sifat-sifat unsur, (d) cara-cara pembuatan unsur di laboratorium dan di industri, (e) kegunaan unsur, (f) pembuatan, sifat-sifat, dan kegunaan senyawaan.

Yang dimaksud dengan peran dalam kegiatan praktikum, antara lain: (1) manager; bertanggung jawab secara penuh atas kelancaran praktikum, (2) analis; bertanggung jawab mempersiapkan dan membuat larutanlarutan kimia yang diperlukan, (3) operator; bertanggung jawab mensetting peralatan dan melaksanakan praktikum, dan (4) juru tulis sekaligus pengamat; bertanggung jawab menuliskan atau mendokumentasikan semua hal yang menyangkut pelaksanaan praktikum.

Yang dimaksud dengan peran pembelajaran teori di kelas antara lain: (1) ketua; bertanggung jawab atas kelancaran diskusi kooperatif dalam kelompoknya, (2) notulen; bertanggung jawab mendokumentasikan kegiatan diskusi kooperatif dalam kelompoknya, (3) presenter; bertanggung jawab mempresentasikan hasil-hasil diskusi kooperatif dalam kelompoknya, dan (4) pengamat/ pemantau; bertanggung jawab mengamati kegiatan diskusi kooperatif dalam kelompoknya. Pada penelitian ini dilaksanakan empat kali (@100 menit) tatap muka dalam bentuk pembelajaran kuliah teori di kelas dan dua kali (@ 180 menit) kegiatan praktikum di laboratorium untuk dua pokok bahasan (nitrogen dan halogen) sehingga setiap anggota kelompok mempunyai kesempatan yang sama untuk melaksanakan peran yang berbeda.

3). Evaluasi; dilakukan dalam bentuk test essay.

\section{Teknik Analisa Data}

Pada penelitian ini digunakan analisa statistik untuk data-data hasil final tes dan pos tes untuk mengetahui hasil belajar mahasiswa, yang diringkas dalam tabel di bawah:

\begin{tabular}{|l|l|}
\hline \multicolumn{1}{|c|}{ Tujuan } & $\begin{array}{c}\text { Teknik Analisa } \\
\text { Data }\end{array}$ \\
\hline $\begin{array}{l}\text { 1. Mendeskripsikan } \\
\text { proses pembelajaran } \\
\text { dari data hasil observasi }\end{array}$ & Analisa Deskriptif \\
\hline 2. Menguji hipotesa & Analisa Statistik \\
\hline
\end{tabular}

Data berupa skor dari final tes dan pos tes selanjutnya dianalisa dengan menggunakan teknik analisa varian (ANAVA) satu jalur. Analisa dilakukan dengan menggunakan program SPSS 15 for windows. Sebagai persyaratan analisa statistik parametrik maka dalam penelitian ini akan dilakukan uji normalitas dan uji homogenitas [1]. Analisa ini digunakan untuk menguji hipotesa yang diajukan. Hipotesa yang akan diuji adalah $\mathrm{H}_{0}$ :

Kriteria pengujian hipotesa adalah $\mathrm{H}_{0}$ diterima jika $\mathrm{F}_{\text {hitung }}<\mathrm{F}_{\text {tabel }}$ dan ditolak jika $\mathrm{F}_{\text {tabel }} \mathrm{d}^{\text {" }} \mathrm{F}_{\text {hitung }}$. Dengan ketentuan apabila $\mathrm{F}_{\text {tabel }} \mathrm{d}$ " $\mathrm{F}_{\text {hitung }}$ maka diinterpretasikan signifikan dan sebaliknya apabila $\mathrm{F}_{\text {hitung }}<\mathrm{F}_{\text {tabel }}$ maka diinterpretasikan tidak signifikan atau tidak ada perbedaan yang signifikan.

\section{HASIL DAN PEMBAHASAN}

\begin{tabular}{|c|c|l|l|c|c|c|}
\hline \multirow{2}{*}{} & \multicolumn{2}{|c|}{$\begin{array}{c}\text { Skor hasil belajar } \\
\text { praktikum }\end{array}$} & \multicolumn{3}{c|}{$\begin{array}{c}\text { Skor hasil belajar } \\
\text { teori di kelas }\end{array}$} \\
\cline { 2 - 7 } & $\mathrm{K}$ & $\mathrm{E}-2$ & $\mathrm{E}-1$ & $\mathrm{~K}$ & $\mathrm{E}-2$ & $\mathrm{E}-1$ \\
\hline $\mathrm{N}$ & 34 & 25 & 25 & 34 & 25 & 25 \\
\hline $\bar{x}$ & 52,8 & 57,6 & 65,0 & 47,1 & 57,2 & 70,7 \\
\hline $\mathrm{SD}$ & 4,7 & 4,9 & 5,1 & 22,9 & 17,1 & 19,1 \\
\hline
\end{tabular}

\begin{tabular}{|c|l|l|l|l|}
\hline Kelas & \multicolumn{2}{|c|}{$\begin{array}{c}\text { Kelompok Terbaik } \\
\text { Prakt ikum }\end{array}$} & \multicolumn{2}{c|}{$\begin{array}{c}\text { Kelompok Terbaik } \\
\text { Teori di Kelas }\end{array}$} \\
\hline & $\begin{array}{l}\text { Pokok } \\
\text { Bahasan }\end{array}$ & Pokok & Pokok & Pokok \\
& Nitrogen & Halogen & Bahasan & Bahasan \\
Nitrogen & Halogen \\
\hline E-1 & I & I & I & I \\
\hline E-2 & VI & VI & VI & VI \\
\hline
\end{tabular}

Keterangan:

$\mathrm{K}=$ Kelas Kontrol; E-1 = Kelas Eksperimen-1; E-2 $=$ Kelas Eksperimen-2;

$\bar{x}=$ Skor Rata-rata Nitrogen dan Halogen;

$\mathrm{N}=$ Jumlah Mahasiswa;

$\mathrm{SD}=$ Standard Deviasi. 
Perbandingan Hasil Belajar Kuliah Teori di Kelas Antara Pendekatan Pembelajaran Kooperatif Tipe LT Yang Dimodifikasi Dengan Berganti Peran (Kelas E-1) dan Peran Tetap (Kelas E-2) dan Pendekatan Pembelajaran Ceramah (Kelas K)

Hasil pengujian menunjukkan bahwa hasil belajar dengan penerapan pendekatan pembelajaran kooperatif tipe $L T$ yang dimodifikasi dengan berganti peran lebih baik dibanding hasil belajar yang dimodifikasi dengan peran tetap dan pendekatan pembelajaran verifikasi. Hasil ini bisa terjadi diduga karena pembelajaran kooperatif berganti peran dan peran tetap dapat menciptakan suasana pembelajaran yang memungkinkan mahasiswa lebih bebas dan lebih berani berdiskusi dengan teman sesama anggota dibanding kelas kontrol. Juga memungkinkan mahasiswa lebih berani mengeksplorasi kemampuan dirinya dalam rangka mencari pemecahan masalah yang dihadapi.

\section{Kelas Kontrol vs Kelas E-1}

Hasil penelitian menunjukkan skor hasil belajar di kelas dimana kelas E-1 lebih baik dibanding kelas kontrol. Dengan mengikuti kaidah-kaidah pendekatan kooperatif yang dilaksanakan dengan baik, mahasiswa memperoleh keuntungan yang lebih besar dibanding pada pendekatan konvensional, karena dalam pendekatan kooperatif terjadi diskusi dalam kelompok kecil, tugas bersama, rasa swim and sink together dan tutor sebaya sehingga mahasiswa lebih bebas dan lebih berani mengeksplorasi kemampuan dirinya.

Berdasarkan pengamatan peneliti, diskusi di kelas E-1 berjalan sangat baik walau sedikit agak "riuh", dimana tiap anggota kelompok berani berdebat, bertanya, dan menjelaskan yang menjadikan pembelajaran menjadi sangat dinamis. Pada kelas E-1 ini, terjadi pergantian peran yang dapat meningkatkan semangat dan rasa tanggung jawab tiap anggota kelompok untuk melakukan tugasnya masing-masing dengan baik sehingga tiap anggota kelompok berusaha melakukan perannya sebaik mungkin untuk memperoleh hasil belajar yang lebih baik.

\section{Kelas Kontrol vs Kelas E-2}

Penelitian ini menunjukkan bahwa mahasiswa yang difasilitasi dengan pendekatan kooperatif tipe $L T$ dengan penekanan pada peran tetap menampilkan hasil belajar yang lebih baik dibandingkan dengan pendekatan verifikasi. Berdasarkan pengamatan peneliti, terjadi kecenderungan yang hampir sama dengan kelas K vs E-1 dimana mahasiswa berusaha melaksanakan pembelajaran dengan kaidah-kaidah pendekatan kooperatif dengan baik. Perlu untuk diketahui bahwa "keceriaan" mahasiswa dalam berdiskusi, berdebat, bertanya, dan menjelaskan tidak "seceria" kelas E-1.

\section{Kelas E-1 vs Kelas E-2}

Penelitian ini menunjukkan bahwa mahasiswa yang difasilitasi dengan pendekatan kooperatif tipe $L T$ dengan penekanan pada berganti peran menampilkan hasil belajar yang lebih baik dibandingkan dengan penekanan pada peran tetap. Hasil ini bisa terjadi kemungkinan karena perbedaan karakter mahasiswa, dimana mahasiswa kelas E-2 lebih pasif dibanding mahasiswa kelas E-1 dalam berdiskusi, berdebat, bertanya, menjelaskan, dan tutor sebaya. Dari pengamatan peneliti juga diketahui bahwa dalam kedua penekanan pembelajaran ini, secara umum terjadi interaksi yang cukup baik diantara anggota dalam satu kelompok sejak awal hingga akhir pembelajaran.

\section{KESIMPULAN}

Berdasarkan hasil penelitian, pembahasan, dan analisis data, maka dapat dikemukakan beberapa kesimpulan sebagai berikut:

1. Ada perbedaan hasil belajar Kimia Anorganik 1 antara kelompok mahasiswa yang diajar dengan pendekatan pembelajaran kooperatif tipe $L T$ yang dimodifikasi dengan berganti peran dan kelompok mahasiswa yang diajar dengan pendekatan pembelajaran verifikasi, dimana modifikasi dengan berganti peran memberikan hasil belajar yang lebih baik dibanding pendekatan pembelajaran verifikasi.

2. Ada perbedaan hasil belajar Kimia Anorganik 1 antara kelompok mahasiswa yang diajar dengan pendekatan pembelajaran kooperatif tipe $L T$ yang dimodifikasi dengan peran $t$ etap dan kelompok mahasiswa yang diajar dengan pendekatan pembelajaran verifikasi, dimana modifikasi dengan peran tetap memberikan hasil belajar yang lebih baik dibanding pendekatan pembelajaran verifikasi.

3. Ada perbedaan hasil belajar Kimia Anorganik 1 antara kelompok mahasiswa yang diajar dengan pendekatan pembelajaran kooperatif tipe $L T$ yang dimodifikasi dengan berganti peran dan kelompok mahasiswa yang diajar dengan pendekatan pembelajaran kooperatif tipe $L T$ yang dimodifikasi dengan peran tetap, dimana modifikasi dengan berganti peran memberikan hasil belajar yang lebih baik dibanding modifikasi dengan peran tetap.

\section{DAFTAR PUSTAKA}

[1] Arikunto, S. 1997. Prosedur Penelitian: Suatu Pendekatan Praktek. Jakarta: Rineka Cipta

[2] Azwar, S. 2001. Reliabilitas dan Validitas, edisi revisi, Jogjakarta: Pustaka Pelajar

[3] Ibnu, S., Mukhadis A. \& Dasna I.W. 2003. Dasardasar Metodologi Penelitian, Penerbit Universitas Negeri Malang.

[4] Ibnu, S. 2006. Model-model Pembelajaran Konstruktif dalam Pembelajaran Sains Kimia. Malang; Jurusan Kimia UM

[5] Johnson, D.W., Johnson, R.T., \& Stanne, M.E. 2000. Cooperative Learning Methods: A MetaAnalysis. On-line: http://www.co-operation.org/ pages/cl-methods.html. Diakses tgl. 17 Maret 2006.

[6] Rahayu, S. 2005. Implementasi Pembelajaran Kooperatif di Perguruan Tinggi, M a k a la h Seminar dan Lokakarya Pembelajaran Konstruktif, Jurusan Kimia, PMIPA, UM, 23 Juni 2005

[7] Slavin, R. E. 1995. Cooperative Learning. Massacchusset; Allyn \& Bacon

[8] Tuckman, B. W. 1999. Conducting Educational Research, fifth edition, New York; Harcourt Brace College Publisher 